\title{
ИСТОЧНИКОВЕДЕНИЕ
}

\section{Проблема вероисповедания бурят в трудах Ц. Ж. Жамцарано (1900-е гг.)}

\author{
Ширап Цьљенович Цьљәэнэ
}

${ }^{1}$ Институт монголоведения, буддологии и тибетологии СО РАН (д. 6. ул. Сахьяновой, 670047 Улан-Удэ, Российская Федерация) аспирант, младший научный сотрудник

iD 0000-0003-4207-5775. Email: tsydens@outlook.com

(C) КалмНЦ РАН, 2021

(С) Цыдэнэ Ш. Ц., 2021

Аннотация. В статье рассмотрена проблема вероисповедания бурят в трудах Ц. Ж. Жамцарано в 1900-е гг. Цель исследования заключается в определении специфики в постановке исследовательской проблемы в трудах Ц. Ж. Жамцарано. Поставленные в статье задачи: проанализировать влияние научной и общественной деятельности Ц. Ж. Жамцарано на ход его творческой мысли; сопоставить трактовку Ц. Ж. Жамцарано с воззрениями по данной проблеме одного из выдающихся исследователей бурятской истории М. Н. Богданова. Анализ влияния историко-культурной среды на рассуждения Ц. Ж. Жамцарано обуславливает необходимость сопоставления сведений из дневников ученого, которые велись в ходе этнографических экспедиций по этнической Бурятии в 1903-1906 гг., и его опубликованных трудов в рамках заданной хронологии. В результате были раскрыты ключевые позиции Ц. Ж. Жамцарано в отношении религиозного движения бурят в начале XX в. Bblвoдbl. Из анализа трудов Ц. Ж. Жамцарано следует, что бурятское религиозное движение имело долгую историю, за которую сформировались этнотерриториальные особенности этого движения. Причина его ускорения в 1900-е гг. состояла в обширном недовольстве бурят господствующей у них религией, это спровоцировало поиски новых путей духовного развития. В отношении направленности этого движения Ц. Ж. Жамцарано определил общее русло в движении к культурному панмонголизму. Данная трактовка пришла к ученому в ходе активного участия в общественной деятельности по культурному возрождению бурятского народа. Кроме того, в интерпретации Ц. Ж. Жамцарано религиозное движение бурят в 1900-е гг. не противоречило общемировой тенденции по секуляризации просвещения.

Ключевые слова: историография, этнография, религия, «инородческий вопрос», буддизм, просвещение, Ц. Ж. Жамцарано, М. Н. Богданов

Благодарность. Статья подготовлена в рамках государственного задания — проект «Письменные традиции народов Байкальского региона в контексте историко-культурного наследия России и Внутренней Азии (номер госрегистрации: 121031000263-3).

Для цитирования: Цыдэнэ Ш. Ц. Проблема вероисповедания бурят в трудах Ц. Ж. Жамцарано (1900-е гг.) // Монголоведение. 2021. Т. 13. № 3. С. 496-503. DOI: 10.22162/25001523-2021-3-496-503 


\title{
The Question of Religious Confession among Buryats in Ts. Zhamtsarano's Works, 1900s
}

\author{
Shirap Ts. Tsydene ${ }^{1}$
}

${ }^{1}$ Institute for Mongolian, Buddhist and Tibetan Studies of the Siberian Branch of the RAS (6, Sakhyanova St., 670047 Ulan-Ude, Russian Federation)

Postgraduate Student, Junior Research Associate

(iD) 0000-0003-4207-5775. Email: tsydens@outlook.com

(C) KalmSC RAS, 2021

(C) Tsydene Sh. Ts., 2021

\begin{abstract}
The article aims to analyze the issue of Buryat religious views as discussed in the works of Ts. Zhamtsarano in the 1900s. The purpose of the study is to identify the specifics of Zhamtsarano's approach in the formulation of the research issue. In particular, the article analyzes the impact of his scientific and social activities on the course of his creative thought, as well as compares his interpretation of Buryat religious movement with that of M. N. Bogdanov, one of outstanding researchers of Buryat history. To analyze the impact of his cultural-historical environment on Zhamtsarano's views, it was necessary to examine the scholar's diaries he kept at the time of his ethnographic expeditions in Buryatia in 1903-1906 in comparison with his published works of the same period. As a result, it was possible to identify his key positions on the issue of the Buryat religious movement in the early twentieth century. Conclusions. The analysis of Zhamtsarano's works shows that the Buryat religious movement had a long history, with its ethnoterritorial features gradually being formed. The reason for its acceleration in the 1900s was that many Buryats at the time were largely dissatisfied with their dominant religion, hence their search for new forms of spirituality. According to Zhamtsarano, the general direction of this movement was towards cultural pan-mongolism; this conclusion was based on his own active involvement in the activities for the Buryat cultural renaissance. Also, the scholar saw the religious movement of the Buryats in the 1900s as part of the global trend for secularization of the enlightenment.
\end{abstract}

Keywords: historiography, ethnography, religion, the question of inorodtsy (non-Russians), Buddhism, enlightenment, Ts. Zhamtsarano, M. N. Bogdanov

Acknowledgements. The reported study was funded by government assignment, project no. 121031000263-3 'Writing Traditions of Baikal Peoples in the Context of Historical and Cultural Heritage of Russia and Inner Asia'.

For citation: Tsydene Sh. Ts. The Question of Religious Confession among Buryats in Ts. Zhamtsarano's Works, 1900s. Mongolian Studies (Elista). 2021; 13 (3): 496-503. (In Russ.). DOI: 10.22162/2500-1523-2021-3-496-503

\section{Введение}

Научное наследие Цыбена Жамцарановича Жамцарано (1881-1942) с каждым годом находит новое прочтение. Открываются новые грани его творческой мысли, не только «как этнографа, публициста и общественного деятеля, но и как яркой и неповторимой личности» [Жамцарано 2011: 5]. Бурятский ученый находился «на острие событий» в начале XX в., совмещая в одном лице роль исследователя и актора в разворачивающихся в стране исторических процессах. Уникальной чертой творческой мысли ученого стала опора на широкий источниковый материал социологического характера, который был собран и отражен 
им в дневниках. Дневники он вел в ходе этнографической работы по изучению и сохранению фольклорной традиции бурят в многочисленных экспедициях по всей этнической Бурятии. Именно там Ц. Ж. Жамцарано сформулировал свое отношение к проблеме вероисповедания бурят в начале XX в., которое он четко обозначил следующим образом: «Мы не знаем ни одного народа, который оставался бы при одной религии», а человек «прогрессирует, растет его умственный кругозор, нравственный идеал становится выше, развивается критический ум; сообразно с этим и религия его растет, становится выше, разумнее» [Жамцарано 2021: 74].

В статье поставлена цель - проанализировать проблему вероисповедания бурят в трудах Ц. Ж. Жамцарано в 1900-е гг. и определить специфику в постановке исследовательской проблемы, раскрыть размышления ученого и проследить ход его творческой мысли по вопросам веры в бурятском обществе.

Для достижения этой цели в исследовании были использованы историко-сравнительный и историко-типологический методы. С применением принципа историзма были проанализированы элементы историко-культурной среды, отраженные в творческой мысли Ц. Ж. Жамцарано. Так, были охарактеризованы истоки исследовательских концепций ученого в отношении религиозного движения бурят в 1900-е гг. Концептуализация размышлений ученого потребовала использование историко-сравнительного и историко-типологического методов. Так, применение этих методов реализовано при анализе дискуссии между М. Н. Богдановым и Ц. Ж. Жамцарано. В итоге мы определили ряд ключевых позиций Ц. Ж. Жамцарано по отношению к проблеме религиозного движения бурят в 1900-е гг.

Дискуссия М. Н. Богданова и Ц. Ж. Жамцарано о религиозном движении иркутских бурят в 1900-е гг. Рамки исследовательской проблематики в трудах Ц. Ж. Жамцарано

Невозможно в полной мере отразить специфику единственного мнения без его сопоставления и сравнения с другими. Для этого как нельзя лучше подходит дискуссия, развернувшаяся между Ц. Ж. Жамцарано и М. Н. Богдановым. Таковой ее делает диаметральная противоположность взглядов оппонентов. Ученые отразили в дискуссии как личные раздумья, так и характерные черты социально-политической платформы конкурирующих течений бурятского национального движения национальных-демократов и «обрусителей».

Для постановки проблемы нужно представить мнение М. Н. Богданова. Он порицал и критиковал позицию Ц. Ж. Жамцарано по распространению среди бурят буддизма, укреплению роли дацанов в жизни бурятского общества в качестве центров нравственного воспитания и борьбы с грубыми нравами, под последними понималось пьянство и прочие проявления социальной маргинализации [Богданов 1907: 38-50]. М. Н. Богданов считал своим долгом критиковать те социальные тенденции, которые считал противными делу бурятского возрождения [Богданов 1907: 48].

Предметом дискуссии между М. Н. Богдановым и Ц. Ж. Жамцарано стало наметившееся в начале XX в. движение иркутских бурят к буддизму. М. Н. Богданов объяснил этот процесс прежде всего ошибками православного миссионерства и возложил ответственность пропагандистов буддизма на цаннид-хам- 


\section{Источниковедение}

бо А. Л. Доржиева и самого Ц. Ж. Жамцарано, которые в союзе с бурятской «знатью» распространяли буддизм среди иркутских бурят. Для подтверждения своего тезиса М. Н. Богданов приводит слова неких респондентов-бурят из Иркутского уезда [Богданов 1907: 39, 41].

Цель этой пропаганды он видит чисто утилитарной, направленной на разрешение социальных проблем бурятского народа: снижение общественных и индивидуальных трат на религиозные нужды; развитие тибетской медицины; распространение буддийского просвещения [Богданов 1907: 41-42]. Использование буддизма в качестве инструмента при социальном строительстве бурят М. Н. Богданов считал «страшным анахронизмом» и «крайне нежелательным», в потенциале вредным решением для будущего народа [Богданов 1907: 43-44].

В связи с этим общественная деятельность Ц. Ж. Жамцарано по организации просвещения бурят и работы союза бурятских учителей «Буряад зоной туг» также была подвергнута критике как очередная попытка проповедовать буддизм среди всех бурят [Богданов 1907: 43-44].

Это, по мнению М. Н. Богданова, абсолютно противоречило общемировому прогрессивному стремлению отделить дела религии от народного образования [Богданов 1907: 43-44]. Таким образом, М. Н. Богданов заключает, «что описываемое движение отнюдь не является чисто-народным движением, начавшимся с низов народной жизни. Наоборот, оно началось с верхов бурятской социальной лестницы» [Богданов 1907: 40]. Он декларирует их бесполезность, не без симпатии расценивая их как «мечты и грезы» [Богданов 1907: 48].

Нужно понимать, что исследователи не только были знакомы, но и следили за публикациями друг друга. Так, в дневниках Ц. Ж. Жамцарано имеются заметки о встречах с М. Н. Богдановым 3 июля и 10 октября 1906 г., первая встреча была, очевидно, приятельской, и будущий оппонент только вернулся на родину из-за границы, на второй встрече в улусе Курумча Ц. Ж. Жамцарано заметил, что М. Н. Богданов был «очень вооружен против движения среди шаманистов сторону буддизма» и считал его вызванным «Доржиевым, Михайловым, Александровым и мною» [Жамцарано 2011: 215, 229].

Именно так была открыта дискуссия. Нужно заметить, что ее переход в публичную сферу показывает серьезность противоречий и объясняет несдержанность оппонентов в полемике.

Таким образом, был определен предмет дискуссии - это религиозное движение иркутских бурят в сторону буддизма. Основываясь на этом, нужно обозначить рамки проблематики в интерпретации Ц. Ж. Жамцарано.

В серии ответных статей Ц. Ж. Жамцарано не только критикует положения оппонента, но и раскрывает свои взгляды, местами поправляя своего визави в тех моментах, где были неправильно поняты или искажены его собственные мысли.

Подход Ц. Ж. Жамцарано к проблеме отличается широтой постановки вопроса. Так он подчеркивает, что «религиозное движение бурят в сторону буддизма не при нас началось и не при нас, может быть, закончится» [Жамцарано 2021: 75]. В поддержку этого тезиса он приводит факт: столетия истории распространения буддизма в Забайкалье и проникновения в Предбайкалье, которое не прекратилось, несмотря на административные и другие препятствия. Помимо истории, он обратил внимание на современные тенденции шаманистов по ре- 
формированию религиозных представлений для удовлетворения духовных нужд народа: «Возникновение культа заянов (богочеловеков), секты поклонников огня и воды, почитатели лебедя, поклонники небесных богов, культ монголов, сторонники „белых“ бескровных жертв - все это признаки искания новых путей, новой религии» [Жамцарано 2021: 75].

В стремлении М. Н. Богданова возложить ответственность буддийского проповедника на него самого, Ц. Ж. Жамцарано видит только необоснованные попытки дискредитировать и так тяжёлое политическое положение союза бурятских учителей «Буряад зоной туг» [Жамцарано 2021: 76]. Это обвинение в итоге привело к публичным разъяснениям со стороны союза учителей, которые подчеркнули, что вопрос преподавания буддизма и других религий действительно рассматривался, но исключительно «как учебный научный предмет», а ученики, прежде всего, изучали бы «историю буддизма, шаманства, ислама и др. религий» [Бурятские учителя... 1907: 28].

\section{Эволюция научной мысли Ц. Ж. Жамцарано по проблеме религиозного движения бурят в 1900-е гг.}

Духовные поиски бурятского народа Ц. Ж. Жамцарано наблюдал в ходе многочисленных экспедиций в 1900-е гг. как по Иркутской губернии, так и в Забайкалье. В первом случае они состояли в «брожении» внутри буддийской сангхи, которое было связано с кризисом иерархического устройства и падения учености лам, а во втором случае население массово переходило в буддизм, разочаровавшись в шаманстве [Жамцарано 2011: 54, 60, 140].

Кроме того, красной нитью в дневниках Ц. Ж. Жамцарано прослеживается личное отношение исследователя к буддизму. Перед кем бы не предстал ученый, - перед простым ламой, монгольским или бурятским, гэбши или ранжамбой, святыми Богдо-Гэгэном или Чойжоном - он, прежде всего, ценил ученость священнослужителей, а местами подтрунивал над излишней театральностью священнодействий, если замечал за ним эгоистический умысел [Жамцарано 2011: 103, 108, 110, 140, 183-184].

Весьма показательна заметка Ц. Ж. Жамцарано о религиозном действии в Цугольском дацане 22-23 июля 1905 г., когда святой Чойжон бился в святом исступлении и его сжимал в руках его помощник: «вид был такой ужасный, потрясающий, что все трепетно сложили руки. Я чуть не вскочил с места с криком: задушат его, несчастный!» [Жамцарано 2011: 185].

Еще более заметен интерес, с которым Ц. Ж. Жамцарано описывает спор Цугольского гэбкуя (инспектор цанитского факультета) с Чойжоном. Предметом спора стало намерение святого «дать ученые степени габжу некоторым ламам», тем самым нарушить установленный в храме порядок обучения и испытания претендентов на данный сан, что обесценило бы распространенный в бурятской сангхе сан гэбши [Жамцарано 2011: 182].

Подробно Ц. Ж. Жамцарано описывает брожение в Агинском и Анинском, крупнейших дацанах хори-бурят, между партиями священнослужителей — гэбшинарами и ранжамбарами - по вопросу регламентации иерархии. Ученый был вынужден принять сторону «винаистов-пандидцев, требуя или коренной реформы, не нарушая винаи, или же прекращения споров и оставления в силе существующего порядка», воспретив или ограничив сбор пожертвований, 


\section{Источниковедение}

необходимый для собрания и организации испытаний на получение ученых санов в связи с их экономической обременительностью для общества [Жамцарано 2011: 141]. Потому как для угощения лам в больших дацанах, в которых ученики насчитывают сотни человек, претендентам приходилось привлекать родственников и целые общества для финансирования этого большого мероприятия [Жамцарано 2011: 139-140].

Все это делалось для отличия ученых лам, потому как «стало невозможно отличить по внешним признакам действительных ученых от профанов» [Жамцарано 2011: 140]. Отсюда видно, насколько большое значение Ц. Ж. Жамцарано уделял учености, дисциплине и моральным добродетелям представителей буддийской веры. Именно в этом он видел потенциал, способность к улучшению бурятского общества. Это ясно видно в симпатии ученого к Токчинскому дацану, который «едва ли не единственный дацан, выдержавший характер буддийского скромного, серьезного, дисциплинированного монастыря - вихары» [Жамцарано 2011: 196]. Более того, ученый противопоставляет ученость лам больших Агинского и Цугольского дацанов нравственности Тогчинских лам, а в беседе с одним из них он приходит к мысли «о суетности и невежестве массы и большинства лам, о поклонении внешности, а не духу, идеалу буддизма» [Жамцарано 2011: 192, 197].

Должно быть, именно в этом нравственном совершенстве, свободе от суеверий и преданности буддийской морали Ц. Ж. Жамцарано видел благотворный потенциал буддизма для нравственного роста бурят. А деятельность Чойжона, открыто объявившего войну шаманству в Забайкалье, удостоилась меткого замечания ученого, он описывает его так: «борьба велась против суеверия посредством суеверия же» [Жамцарано 2011: 195].

Бывало, что Ц. Ж. Жамцарано сталкивался с фанатичными буддистами. Например, он описывает случай, когда «ламы-учителя запретили (рапсодам) заниматься нечистым, черным делом», под чем они понимали народный фольклор, который в их интерпретации являлся признаком дикости бурят [Жамцарано 2011: 166].

Феодальные порядки, которые Ц. Ж. Жамцарано наблюдал на поклоне у монгольского Богдо-Гэгээна, когда паломников, прибывших получить благословение святого, «ругали, кричали, как никто, и били нещадно», вызвали гнев ученого, который ему пришлось унять и «проглотить горькую пилюлю» [Жамцарано 2011: 108].

Ц. Ж. Жамцарано четко осознавал всю трудность изучения народного вероисповедания, в духе истинного критического мышления он подчеркивает: «Мне до сих пор не удавалось точнее выделить элементы шаманистские, ламаистские, буддийские и посторонние не только по отношению к массе, но даже к одному лицу» [Жамцарано 2011: 161].

Таким образом, Ц. Ж. Жамцарано постулировал необходимость фундаментального исследования вопроса о состоянии современного вероисповедания бурят, «чтобы прийти к определенным выводам» [Жамцарано 2011: 161].

Несмотря на это, общие тенденции ученый уловил четко - это недовольство господствующей формой религии как в Иркутской губернии, так и в Забайкалье. Источник этого недовольства, порождающего поиски новых смыслов, 
Ц. Ж. Жамцарано, несомненно, видит в глубоком социально-экономическом расстройстве бурятского общества, о чем он прямо говорил за два года до дискуссии с М. Н. Богдановым [Жамцарано 2021: 75]. Это мнение было присуще как М. Н. Богданову, так и Ц. Ж. Жамцарано [Жамцарано 2011; Богданов 1907: 43].

Несомненно, Ц. Ж. Жамцарано видит духовную жизнь бурятского общества свободной от мистицизма: «утилитарность» его представлений продиктована стремлением к национальной консолидации бурят на принципах полной свободы совести и вероисповедания, воплощая на деле идею «единство в многообразии» [Жамцарано 2011: 40, 46].

Данная трактовка проблемы вероисповедания бурят формируется у Ц. Ж. Жамцарано не только в ходе научных экспедиций, благодаря которым он имел возможность объездить множество бурятских мест и общаться с различными людьми, но и в ходе участия в работе национальных съездов бурят Иркутской губернии и Забайкалья, на которых в качестве предмета общественного обсуждения был выдвинут вопрос о доработке «Положения о ламайском духовенстве» (принятого в 1853 г.) или необходимости коренной реформы духовной жизни бурят [Жамцарано 2011: 136, 159, 178]

\section{Выводы}

В ходе наблюдения за духовными поисками бурятского народа, а также участия в первых шагах бурятского национального движения Ц. Ж. Жамцарано сформулировал концепцию бурятского религиозного движения в русле культурного панмонголизма [Жамцарано 2011: 217]. Особенно его поразило самосознание молодых учащихся бурят, взявшихся изучать буддизм в свободное от учебы время, в чем ученый увидел их «замечательно сознательное отношение к переживаемому бурятами времени» [Жамцарано 2011: 138].

Неотъемлемой частью этого возрождения Ц. Ж. Жамцарано видел борьбу против «ограничительных мер, в силу которых буряты, как иноверцы, не принимаются» в светские образовательные учреждения «наравне с другими группами населения» [Жамцарано 2021: 31]. Более того, его рассуждения масштабировались на государственный уровень и обретали форму требований «инородческого» представительства в Государственной думе Российской империи [Жамцарано 2011: 68].

Таким образом, мы обнаружили в наблюдениях и творческой мысли Ц. Ж. Жамцарано ряд ключевых позиций в отношении вопроса вероисповедания бурят в начале XX в., которые сформировались у ученого в ходе продолжительной научной и общественной деятельности.

Во-первых, бурятское религиозное движение в начале ХХ в. являлось сложным и разнообразным историческим процессом. Этот процесс имеет долгую историю с самого начала проникновения буддизма к бурятам в конце XVIIXVIII вв., и он постепенно охватывал все земли и этнотерриториальные группы бурят, отсюда их региональная и местная специфика. Для всех проявлений религиозного движения бурят в начале XX в. Ц. Ж. Жамцарано выделил два общих фактора: 1) недовольство господствующей религией; 2) поиски новых путей духовного развития общества.

Во-вторых, бурятское религиозное движение закономерно стремилось к культурному панмонголизму. Данная трактовка, очевидно, пришла к Ц. Ж. Жам- 


\section{Источниковедение}

царано в ходе активного вовлечения в общественную деятельность в рамках бурятского национального движения в начале XX в., она значила приобщение бурят Иркутской губернии и Забайкалья к общей для всех монгольских народов духовной и письменной культуре [Жамцарано 2011: 217].

В-третьих, бурятское религиозное движение, по убеждению Ц. Ж. Жамцарано, не противоречило общемировым тенденциям по секуляризации знания, преодолению межнациональных культурных барьеров и другим формам интеграции в общероссийское и мировое культурное пространство. Ученый считал, что развитие общего просвещения не противоречит развитию религиозной жизни общества.

\section{Источники и литература}

Богданов 1907 - Богданов М. Н. Бурятское возрождение // Сибирские вопросы. 1907. № 3. C. 38-49.

Бурятские учителя 1907 - Бурятские учителя на учительском съезде. Устав бурятского союза учителей и деятелей по народному образованию (Буряад зоной туг) //

Сибирские вопросы. 1907. № 19. С. 24-28.

Жамцарано 2011 - Жамиарано Ц. Ж. Путевые дневники. 1903-1907 гг. / сост.:

Ц. П. Ванчикова, В. Ц. Лыксокова, И. В. Кульганек. Улан-Удэ: Респ. тип., 2011. $264 \mathrm{c}$.

Жамцарано 2021 - Жамицарано Ц. Ж. Избранные труды / сост.: Ц. П. Ванчикова,

Б. Б. Балбарова, С. Б. Дарижапова. Улан-Удэ; Агинское: Респ. тип., 2021. 160 с.

\section{References}

Bogdanov M. N. Buryat renaissance. Sibirskie voprosy. 1907. No. 3. Pp. 38-49. (In Russ.) Buryat teachers at Teachers' Congress. Charter of Buryat Association of Teachers and Public Education Workers. Sibirskie voprosy. 1907. No. 19. Pp. 24-28. (In Russ.)

Zhamtsarano Ts. Zh. Selected Works. Ts. Vanchikova et al. (comps.). Ulan-Ude, Aginskoye: Respublikanskaya Tipografiya, 2021. 160 p. (In Russ.)

Zhamtsarano Ts. Zh. Travel Notes, 1903-1907. Ts. Vanchikova et al. (comps.). Ulan-Ude: Respublikanskaya Tipografiya, 2011. 264 p. (In Russ.) 